UDC: 330.3

\title{
V. Boskova,
}

Applicant of the first (bachelor's) level of higher education in the specialty "Economics", Kherson Branch of Admiral Makarov National University of Shipbuilding, Kherson, Ukraine ORCID ID: 0000-0002-2076-5866
A. Rusnak,
Doctor of Economic Sciences, Professor, Professor of the Department of Economics, Kherson Branch of Admiral Makarov National University of Shipbuilding, Kherson, Ukraine ORCID ID: 0000-0002-3198-2866

\section{Nadtochii,}
Doctor of Economic Sciences, Associate Professor, Professor of the Department of Economics, Kherson Branch of Admiral Makarov National University of Shipbuilding, Kherson, Ukraine ORCID ID: 0000-0003-0693-8000

\section{THE ESSENCE OF BUSINESS-PROCESSES AND PROCESS-ORIENTED MANAGEMENT IN AGRICULTURAL ENTERPRISES}

\author{
В. В. Боскова, \\ здобувач першого (бакалаврського) рівня вищої освіти за спеціальністю "Економіка", Херсонська \\ філія Національного університету кораблебудування імені адмірала Макарова, м. Херсон, Україна \\ А. В. Руснак, \\ А. е. н., професор, професор кафедри економіки, Херсонська філія Національного університету \\ кораблебудування імені адмірала Макарова, м. Херсон, Україна \\ I. I. Надточій, \\ А. е. н., доцент, професор кафедри економіки, Херсонська філія Національного університету \\ кораблебудування імені адмірала Макарова, м. Херсон, Україна
}

\section{СУТНІСТЬ БІЗНЕС-ПРОЦЕСІВ ТА ПРОЦЕСНО-ОРІЕНТОВАНОГО УПРАВАІННЯ У СІАЬСЬКОГОСПОААРСЬКИХ ПІАПРИЄМСТВАХ}

The article describes four main approaches in enterprise management: historical, functional, systemic, situational It has been determined that the process approach allows to take into account such important aspects of the business as the focus on the final product, the interest of each performer in improving the quality of the final product and, consequently, interest in completing the work. The essence of the category "business-process" has been investigated. The main elements of the structure of the business-process of an agricultural enterprise have been identified and characterized: the owner responsible for its implementation; input; output; management and resources. The distinctive features of the businessprocess of agricultural enterprises have been generalized. Based on this, the business-process of an agricultural enterprise has been defined as a set of successive technologically interconnected operations that use industry-specific resource planning as input and the organization of actions to solve problems as output, applying controlling principles that create products that play strategic role in the livelihood of society and is of value to consumers. The classification of businessprocesses of agricultural enterprises is given and their main types are characterized: business-processes of production or main processes, auxiliary or service business-processes, providing business-processes and development businessprocesses. It has been proved that the management of business-processes of agricultural enterprises has its own specifics due to the peculiarities of agriculture. The main advantages of process-oriented management of agricultural enterprises have been highlighted. It has been determined that in order to build an effective business-process management system of agricultural enterprises it is necessary to take into account the interaction of three main elements - key business-processes, enterprise subsystems and types of consumers. When building such a system, it is necessary to take into account industry specifics, the presence of a formalized strategy and long-term planning, the size of the enterprise, as well as the impact of macroeconomic factors. 
У статті охарактеризовано чотири основні підходи в управлінні підприємством: історичний, функціональний, системний, ситуаційний. Визначено, що процесний підхіА дозволяє врахувати такі важдиві аспекти бізнесу, як орієнтація на кінцевий продукт, зацікавленість кожного виконавця у підвищенні якості кінцевого продукту і, як наслідок, зацікавленість у кінцевому виконанні роботи. Аосліджено сутність категорії "бізнес-процес". Визначено та охарактеризовано основні елементи структури бізнес-процесу сільськогосподарського підприємства: власник, відповідальний за його виконання; вхіА; вихіА; управління та ресурси. Узагальнено характерні риси бізнес-процесу сільськогосподарських підприємств. На основі цього бізнес-процес сільськогосподарського підприємства визначено як сукупність послідовних технологічно взаємопов'язаних операцій, що використовують на вході планування ресурсів, зумовлених специфікою галузі, та організацію дій з вирішення завдань, на виході, застосовуючи принципи контролінгу, що створюють продукцію, яка відіграє стратегічну роль у життєзабезпеченні суспільства та становить цінність Аля споживачів. Наведено класифікацію бізнес-процесів сільськогосподарських підприємств та охарактеризовано їх основні види: бізнес-процеси виробництва або основні, допоміжні або обслуговуючі бізнес-процеси, забезпечуючі бізнеспроцеси і бізнес-процеси розвитку. Аоведено, що управління бізнес-процесами сільськогосподарських підприємств має власну специфіку, яка зумовлена особливостями сільського господарства. Виділено основні переваги процесноорієнтованого управління сільськогосподарськими підприємствами. Визначено, що Аля побудови ефективної системи управління бізнес-процесами сільськогосподарських підприємств необхідно враховувати взаємодію трьох основних елементів - ключових бізнес-процесів, підсистем підприємства та видів споживачів. При побудові такої системи необхідно врахувати галузеві особливості, наявність формалізованої стратегії та довгострокового планування, розмір підприємства, а також вплив макроекономічних чинників.

Keywords: business process, process approac, management, organization, agricultural enterprise.

Ключові слова: бізнес-прочес, прочесний підхід, управління, організачіл, сільськогосподарське підприємство.

\section{FORMULATION OF THE PROBLEM}

Current trends in Ukraine's economy, intensification of market competition require agricultural enterprises to increase their competitive potential by introducing innovative methods and approaches to management practices that can quickly respond to changes in the external environment. At the same time, managers of agricultural enterprises and rural entrepreneurs focus on improving the technology of agricultural production, mostly ignoring the new approaches in management.

Improving of business-processes is one of the main tools for improving the efficiency of entrepreneurial activity. This is primarily due to increased competition from foreign producers, as well as high dynamics of business environment development. Therefore, for managers of agricultural enterprises an important task is to form a mechanism for improving business-processes, which allows to adapt the management system to changes in the external environment in undetermined conditions, which ensures their high efficiency and competitiveness. In this regard, the issues of improving the management of business-processes of agricultural enterprises and improving the efficiency of their activity on the basis of effective process management are important and relevant.

By managing processes and constantly improving them, the company achieves high efficiency of its activities. That is why the process-oriented approach to enterprise management has become the basis of quality management system standards, designed based on the world experience of leading companies. Business-process management helps to reduce downtime, optimize the use of resource potential, reduce financial costs, improve the efficiency of the organization and the quality of enterprise functioning, increase staff motivation. A process-oriented approach to enterprise management allows to accurately determine the ultimate goals and results of the enterprise, and helps to identify the contribution of each employee in achieving these results.

\section{ANALYSIS OF RECENT RESEARCH AND PUBLICATIONS}

The theoretical and methodological basis of the research in the field of management are the works of foreign scientists I. Ansoff, E. Deming [1], P. Drucker, P. Kaplan, A. Marshall, M. Mescon, M. Porter [2], F. Taylor [3] and others. J. Brocke [4], T. Davenport [5], M. Zairi [6], S. Zelt [4], V. Eliferov [7], K. Loginov [8], Y. Oikhman [9], E. Popov [9], J. Recker [4], V. Repin [7; 10; 11], M. Hammer [12], J. Champy [12], T. Schmiedel [4], J. Short [5] devoted their works to the problems of application of the process approach in the management of organizations. Issues of business-process management of agricultural enterprises are reflected in the works of such domestic scientists as A. Zheleznyak, I. Ivanytsky [13], T. Yavorska [14] and others. 
Table 1. The main approaches in enterprise management

\begin{tabular}{|l|l|}
\hline Approaches & \multicolumn{1}{|c|}{ Characteristic } \\
\hline Historical & $\begin{array}{l}\text { Is based on highlighting different schools of thought, } \\
\text { namely: a) scientific management; b) administrative } \\
\text { management; c) human relations and the science of } \\
\text { behavior; d) management science or quantitative methods }\end{array}$ \\
\hline Functional & $\begin{array}{l}\text { Management is seen as a continuous series of interrelated } \\
\text { management functions: planning, organization, motivation, } \\
\text { control }\end{array}$ \\
\hline Systemic & $\begin{array}{l}\text { The organization is perceived as a system of } \\
\text { interdependent elements, such as people, structure, tasks } \\
\text { and technology, which are aimed at achieving certain goals } \\
\text { in a changing environment }\end{array}$ \\
\hline Situational & $\begin{array}{l}\text { Concentrates on the fact that the suitability of different } \\
\text { management methods is determined by the specific } \\
\text { situation. Because there is such a variety of factors and } \\
\text { their combinations that determine the situation, both in the } \\
\text { organization and in the external environment, there is no } \\
\text { single "best" method of managing the organization. The } \\
\text { most effective method in a particular situation is the } \\
\text { method that best suits that situation }\end{array}$ \\
\hline Process & $\begin{array}{l}\text { All activities of the company are perceived as a network of } \\
\text { interacting processes that take place within the } \\
\text { organizational structure of the company and implement the } \\
\text { purpose of its existence }\end{array}$ \\
\hline
\end{tabular}

However, the analysis of the existing theoretical basis of the research topic shows that the theoretical, methodological and practical developments related to the management of agricultural enterprises based on the improvement of business-processes are not yet sufficiently studied. This problem is relevant for various branches of agricultural production.

\section{FORMULATION OF THE GOALS OF THE ARTICLE}

The purpose of the study is to substantiate and develop theoretical aspects to improve the management of business - processes in agricultural enterprises, which contribute to improving the efficiency of their activities.

\section{PRESENTATION OF THE MAIN MATERIAL OF THE STUDY}

Recent decades have been marked not only by the rapid development of machinery and technology, but also by a qualitatively new level of doing business. Problems of effective management of agricultural enterprises come to the fore, methods and management tools of business are being improved. Therefore, the issue of creating an effective management system capable of ensuring the competitiveness of enterprises and the production output corresponding to world counterparts is acute for managers. Customeroriented approach is becoming more widespread, producers and services are changing their behavior in the market and moving from increasing production and sales to maximum customer satisfaction. In these conditions, the use of process- oriented enterprise management system provides tangible benefits, as the system of interdependent and interacting business-processes has the ultimate goal - to create goods or services that are valuable to external and internal consumers.

At this stage of development of theory and practice there are four main approaches to management: historical, functional, systemic, situational (Table 1).

The basis of process management - a complex but effective approach to managing the organization - are business-processes. The process approach is an effective lever of management, it allows to reduce overhead costs and improve product quality, obtain comprehensive information about the current state of business and timely make strategically sound management decisions. Modern theoretical and methodological approaches, such as quality management, optimization and engineering of business-processes, benchmarking, balanced scorecard, etc., as well as a number of information technologies can be fully used only if the process management of the organization is applied.

Process-oriented management has replaced the functional one, which considers the construction of the organization by functions and levels of hierarchy. This organization of management is based on the principle of consistent performance of labor operations, i.e., the labor task is divided into separate operations (tasks, stages), and each employee specializes in performing one of them [3].

The transition to process management allows to identify priority processes that should be improved and developed in order to strengthen the competitive advantage of the enterprise.

The process approach allows to take into account such important aspects of the business as the focus on the final product, the interest of each performer in improving the quality of the final product and, consequently, the interest in completing the work. Processes are the basis of any organizational system and at the same time act as a kind of indicator of the efficiency of economic activity of the organization and its competitiveness. In order to ensure the sustainable and efficient functioning of the enterprise in the long run, it is necessary to constantly improve the businessprocesses carried out on it.

For the first time, the concept of businessprocess was introduced by $\mathrm{M}$. Hammer and J. Champy in the monograph "Reengineering the Corporation: A Manifesto for Business Revolution". They defined a business-process as a set of different activities in which one or more types of 
resources are used as the "input", and as a result of this activity, a product that has value for the consumer is created at the "output" [12].

T. Davenport and J. Short consider the business-process as a set of logically interrelated actions performed to achieve a certain outcome of business activities; structured finite set of actions that are designed for a specific service (product) for a particular consumer or market; specifically ordered set of works, tasks in time and space, indicating the beginning and the end, the exact definition of inputs and outputs; a structured, measurable set of actions designed to make a specific output for a particular customer or market [5]. M. Porter defined the business-process as an entity defined by entry and exit points, interfaces and organizational devices that partially contain the devices of the consumer of services (goods), where the value of the service (goods) is being increased [2]. According to E. Deming, business-processes are any activities in the work of the organization [1]. According to $\mathrm{K}$. Loginov, business-process is a change in the object of the process by transforming material and/ or information flows carried out by functional subjects of the process on a particular technology with the ultimate goal of creating new consumer value or bringing consumer value to the consumer [8]. V. Repin and V. Eliferov give the following definition of the business-process: "a stable, purposeful set of interrelated activities, which, using a certain technology, turns the inputs into outputs that are of value to the consumer" [7]. E. Oikhman and E. Popov define businessprocesses as many internal steps (types) of activities that begin with one or more inputs and end with the production of products required by the customer and satisfy him in cost, durability, service and quality; or as a complete flow of events in a system that describes how a customer starts, runs, and finishes interaction with a business [9]. A business-process is a series of interrelated activities that transform inputs (orders and products) and outputs (products or services) in a given time interval to achieve a specific goal. One of the main differences between a business process and a simple process is its business orientation, i.e. the reflection of economic activity of the enterprise, the result of which is usually a profit $[15$, p. 7]. Business-processes are a systematic and consistent execution of functional operations that bring a specific result [16].

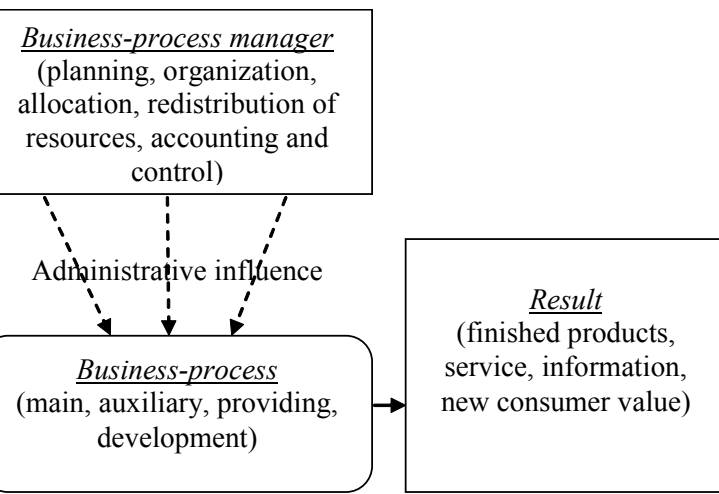

enterprise

Table 2. Basic elements of the business-process structure

\begin{tabular}{|l|l|}
\hline \multicolumn{1}{|c|}{ Element } & \multicolumn{1}{c|}{ Characteristic } \\
\hline Process owner & $\begin{array}{l}\text { An official or a collegiate management body that has the } \\
\text { resources needed to execute the process and is } \\
\text { responsible for the result of the process }\end{array}$ \\
\hline Input & $\begin{array}{l}\text { Material or information used or converted into a } \\
\text { business-process to produce a result (output) }\end{array}$ \\
\hline Output & Product or information produced by a business-process \\
\hline Management & $\begin{array}{l}\text { Rules, technologies, procedures or standards by which a } \\
\text { business-process is guided }\end{array}$ \\
\hline Resources & $\begin{array}{l}\text { A material or information object that is constantly used } \\
\text { to perform the process but is not an input of the process }\end{array}$ \\
\hline
\end{tabular}

In the above authors' definitions $[7 ; 8 ; 12]$ of the category "business-process" the greatest emphasis is placed on the fact that the output is products that have value for consumers, so business-processes are always focused on customer needs. Other authors emphasize the formation of new (added) value at the end of the businessprocess [2].

However, these definitions of "businessprocess" are best suited to enterprises that produce industrial goods, provide consulting or IT services. Therefore, in our opinion, to determine the essential differences of the category "businessprocess of an agricultural enterprise" it is necessary to clearly define the main elements of the businessprocess in agriculture.

The business-process of an agricultural enterprise, like any process, consists of the following basic elements: the owner responsible for its implementation; input; output; management and resources (Fig. 1).

The characteristics of the basic elements of the business-process structure are given in Table 2.

The process owner manages the process and is an integral part of the process [12]. It is allowed that a business-process may not have an input. It should be noted that a business-process without a result has no sense.

The result of the business-process can be: finished products, service, information, new 
Table 3. Classification of business-processes of agricultural enterprises

\begin{tabular}{|c|c|}
\hline $\begin{array}{c}\text { Type } \\
\text { of business- } \\
\text { processes }\end{array}$ & List \\
\hline $\begin{array}{l}\text { Main } \\
\text { (production) }\end{array}$ & $\begin{array}{l}\text { - in the field of crop production (cultivation of cereals and } \\
\text { legumes, industrial crops, fodder, vegetables, melons, stone } \\
\text { fruit, berry crops; production of varietal seeds); } \\
\text { - in the field of animal husbandry (breeding of cattle, pigs, } \\
\text { sheep and goats, rabbits, poultry, fish, horses, bees) }\end{array}$ \\
\hline $\begin{array}{l}\text { Auxiliary } \\
\text { (service) }\end{array}$ & $\begin{array}{l}\text { - equipment repair and maintenance; } \\
\text { - agrochemical service; veterinary and zootechnical services; } \\
\text { - maintenance of technological equipment; } \\
\text { - storage and finalization of products; } \\
\text { - transport service }\end{array}$ \\
\hline Development & $\begin{array}{l}\text { - introduction of innovative communication technologies of } \\
\text { management; } \\
\text { - introduction of resource-saving, knowledge-intensive } \\
\text { technologies; } \\
\text { - modernization of technological lines, equipment, buildings, } \\
\text { premises, storage facilities; } \\
\text { - introduction of high-yielding varieties of agricultural crops } \\
\text { and highly productive breeds of farm animals }\end{array}$ \\
\hline Providing & $\begin{array}{l}\text { - quality system; } \\
\text { - purchases; } \\
\text { - sales; } \\
\text { - staff; } \\
\text { - finance }\end{array}$ \\
\hline
\end{tabular}

create products that play a strategic role in life-supporting of a society and are of value for consumers.

The process approach is extremely promising in terms of modern management theories, however, it should be taken into account that only a comprehensive consideration of all defining factors can lead to the desired result, so we agree with the opinion of scientists [10] that the process approach should be considered jointly with many other decisive factors: structural, financial, personnel, etc.

Most often, the business-processes are visualized using a block diagram of businessprocesses. The technology of the description of business-processes should ensure the transparency of all business operations, which will allow to continually analyze the possible consequences of failures in one or another stage of execution of works, to find and fix the error in a timely manner. Particular attention in the analysis is paid to managing operating consumer value, etc. The resources of the process may include: information, staff, equipment, software, infrastructure, environment, transport, communication, etc. The owner of the process during planning and management of the process carries out allocation and redistribution of resources to achieve the best results of the process. Information can simultaneously refer to the inputs and resources of the process.

For an agricultural enterprise, the features of the business-process are:

- sequence of technologically interconnected actions;

- as resources used at the input and participating in further transformation and development, can be living organisms (working and productive livestock, plants), immobile resources (land), at the output they can reduce or increase their quality;

- "Result" - products received at the output are: a resource used at the input to another business-process; the subject of vital necessity, and which is especially important, the products have a strategic significance, since it maintains the food security of the country from which the quality of life support depends directly.

In this regard, relating to agricultural production, the following definition will be more precise: the business-process of an agricultural enterprise is a set of consistent technologically interconnected operations, which at the input use industry-specific resource planning, and organization of actions for solving tasks, at the output, applying the principles of controlling, expenses, which is one of the main conditions of survival on the market.

In practice, business-processes are usually determined based on the needs of key customers. It is important to provide unimpeded implementation of the process, which will allow the company to increase the added value and maximize the usefulness and value of products and services for its own clients [11].

The business-processes identification and classification at an agricultural enterprise is expedient to perform with a specially formed team, which must necessarily include: heads of departments, specialists who know the problems and technology of the enterprise, and it is desirable to include in a process team and external consultants.

The basis of business-processes classification is four basic categories: main business-processes; providing business-processes; development business-processes; management business-processes.

Specific traits of main business-processes are: processes that create an added value of a product which is produced in a company; processes that create a product which is valuable for external customers; processes the main aim of which is a profit; processes external customers are ready to pay for [12].

An important feature in the classification of business-processes of agricultural enterprises should be noted. Management business-processes are quite difficult to distinguish in isolation from the industry or a particular type of product, so it is advisable to distinguish business-processes of 
production or main processes, auxiliary or service business-processes, providing business-processes and development business-processes (Table 3).

The basis for business-processes classification and identification in agricultural enterprises should be the sectoral division. Thus, the (main) production processes can be divided into businessprocesses in crop production and animal husbandry. The main business-processes of agricultural enterprises also include: agricultural production, enterprise resource management, enterprise finance management, design of the structure of sown areas and livestock, stock management, formation of sales and marketing policy, implementation of quality control system for agricultural products [13, p. 119].

Auxiliary or service business-processes in agricultural enterprises are processes that do not create products, but affect their quality, ensuring timely and flawless implementation of main processes (equipment and technical means repair and maintenance; provision of all types of energy, transportation, storage, services (chemical, veterinary, zootechnical services) In agricultural enterprises, auxiliary business-processes accompany the work of the main processes, namely to meet the production needs of the main agricultural industries (crop and livestock), performing work for them and providing services. Auxiliary business-processes of agricultural enterprises are: agricultural infrastructure management, personnel management, business risk management, information management, legal support management, etc. [13, p. 119].

Development business-processes include the processes of improving the product or service, technology, equipment, and innovation processes. Development business-processes are investment activities where efforts are made today and results are obtained after a certain period. The following business-processes are providing: administrative and economic management, legal support, etc. In contrast to the main processes, number of providing processes reaches several dozen. For agricultural enterprises, we distinguish the providing (management) business-processes that cover the full range of management functions both at the level of departments and organization level in general.

In order to achieve the set goals and defined tasks, as well as to ensure the smooth and flawless execution of any business-process, it is necessary to form a business-process management system in the organization. Business-process management is a comprehensive approach to the implementation of effective business-processes in the organization, which aims to increase the efficiency of organi- zational processes by improving them and implementing innovations [4]. T. Yavorska defines the management of business-processes in the enterprise as an approach to management, focused on optimizing the ways of doing business-processes in organizations [14]. Business-process management is defined as the organization's efforts to analyze and continuously improve production, marketing, communications and other key elements of the company [6].

Using a systems approach to reveal the essence of the category of "business-process management", management is seen as an impact on the system in order to bring it to the desired state. In this case, the system or object of management will be the business-process of the agricultural enterprise, which includes certain consistent, interconnected actions determined by the technology used in the process and the time spent on each operation.

The subject of business-process management is the manager. A term "the owner of process" is often found in the specialized literature. But a more accurate term is "process manager", that performs all the functions of process management and is responsible for achieving the planned results. Individual business-process managers need to be coordinated by a senior manager to achieve the goal more quickly and efficiently.

The management structure is an important element in the business-process management system which should also be defined. In an agricultural enterprise, several subdivisions take part in each business-process, which are differentiated depending on the functional orientation and costs: labor, material, money. Therefore, the structure of business-process management is created in accordance with the division of responsibilities and division of labor between managers, process managers by defining their tasks and powers arising from them. Thus, the structure reflects the relationship of subordination in the management of business-processes.

Management of business-processes of agricultural enterprises has its own specifics due to the peculiarities of agriculture.

1. Dependence on natural factors: soil and climatic conditions, bioclimatic potential of the management area, which determines the specialization of production and is a determining criterion in the selection of business-processes.

2. The main means of production in agriculture is land, the productivity of which depends on fertility. Soil fertility can be maintained in its natural quality, deteriorated or improved, which must be taken into account when planning a production program. 
3. Created products in agricultural enterprises participate in the further production process (seeds and planting material, fodder, young cattle). Therefore, in production management it is important to strive not only to implement the sales plan and ensure revenue, but also to create the necessary natural resources for the next production cycle, which requires additional resources for the construction of premises and industrial facilities. Therefore, providing business-processes in the field of product storage become of great importance.

4. Seasonality of production, which is expressed in the uneven use of resources, sales and cash flow during the year. When planning and allocating business-processes, it is necessary to take into account this feature for optimal use of human resources.

5. The presence of a time interval between production and sale of agricultural products requires the creation of large reserve storages and refrigeration facilities and necessitates primary processing of products. Thus, in the main businessprocess it is necessary to allocate auxiliary business-processes related to the finalization of products. It is also important to plan and justify the amount of capacity required.

6 . Since much of the food is needed in a human diet every day, a large number of people are busy selling it, which significantly increases the share of labor costs not only in production but also in the whole chain of product promotion, from producer to end consumers. In this regard, it is necessary to organize cost accounting to distribute them in business-processes.

In our opinion, the successful implementation of plans for the development of agricultural enterprises is possible in an effective management system based on regulated processes. The process approach has clear advantages over the functional one. When building a process-oriented management system, the main emphasis is on the development of mechanisms of interaction within the process both between structural units within the enterprise and with the external environment, i.e., with consumers, suppliers and partners. It is the process approach that allows to take into account such important aspects of the business as the focus on the final product, the interest of each performer in improving the quality of the final product and, consequently, interest in completing the work.

When managing business-processes of agricultural enterprises, it is important to take a comprehensive approach to the implementation of the functions of planning, control, analysis and cost accounting, which is associated with: mutual influence of efficiency and effectiveness of businessprocesses on each other and on the competitiveness of the enterprise as a whole; the need to timely prevent and eliminate the causes of problems in the implementation of processes, and not solve those already arising with the help of administrative and regulatory measures; the emergence of most problems at the boundaries between business-processes in one classification group and between business-processes of different groups (this is due to the specifics of agricultural production, when one output is raw material at the input of another business-process).

The following main advantages of processoriented management of agricultural enterprises can be identified:

- business-process description technology ensures transparency of all operations not only in the technological chain, but also in structural units, which allows to predict the possible consequences of failures or violations at any stage of work;

- the process approach allows to unite separate actions of functional divisions and to direct their efforts on achievement of the uniform set goal, result;

- allows to increase the motivation of each participant in the process, delegating his powers and responsibilities, while managers are exempt from operational issues and pay more attention to solving strategic tasks;

- high flexibility and adaptability of the process management system, due to greater selfregulation and focus on the final result, taking into account the preferences of consumers and the interests of the enterprise;

- the ability to effectively manage operating costs.

It is important when building the structure of business-processes to prevent a formation of a process management system along with the existing system of functional and administrative management. In this case, the company will have two parallel management systems that must constantly coordinate decisions both in time and space. Two management systems (process and functional) will require two accounting and reporting systems, two resource allocation systems.

In this regard, one of the main tasks of the transition and organization of business-process management in agricultural enterprises is to ensure maximum efficiency of the main processes with a focus on achieving strategic goals. The strategic approach allows to design and manage businessprocesses, providing the ability to quickly change the parameters of inputs and outputs to meet the 
needs of target segments, improve the quality of work, speed up the process if necessary, increase productivity, reduce process cost.

The organization of business-processes in agricultural enterprises allows to implement management innovations based on the allocation of individual structural units - business units and specific business-processes. Through coordinated actions of managers at different levels of management, it is possible to carry out step-bystep management changes, which will provide a choice of key activity consistent with the strategic goals of the organization and develop a realistic budget with the distribution of resources between processes.

When transitioning an enterprise management system to a process-oriented management, there may be problems that will prevent the transformation. The main factor that hinders the effective implementation of a process-oriented approach is the lack of interest of management in achieving the set goals and the passivity of employees at all levels.

The process-oriented approach requires the development and implementation of a new system of staff motivation aimed at encouraging initiative from employees, active participation in the process of developing a project model of businessprocesses, building a network of upper and lower levels processes. These features to varying degrees affect the success of the reform, but only a comprehensive approach to their accounting can contribute to achieving the goals in full. Elimination of such shortcomings of management systems as the closure of structural units on top managers, duplication of functions in units and poor coordination between them, can be achieved through improved business-process management.

\section{CONCLUSIONS}

Organizational and technological features of agricultural enterprises are to build an organizational structure of management on a functional basis, and the territorial extent, the specifics of management have caused some difficulties in applying the process approach. A comprehensive approach to implementation will contribute to the achievement of the set goals in full. It includes, in addition to creating a motivational base for planned changes to involve staff in the process of reforming the management system, phased implementation in the following sequence: description, analysis and regulation of businessprocesses; distribution of responsibilities among the participants in the process; allocation and structuring of business-processes; proposals for process optimization; determination of businessprocess management indicators.

To build an effective business-process management system for agricultural enterprises, it is necessary to take into account the interaction of three main elements - key business-processes, enterprise subsystems and types of consumers. When building such a system, it is necessary to consider industry specifics, the presence of a formalized strategy and long-term planning, the size of the enterprise, as well as the impact of macroeconomic factors.

\section{$\Lambda$ ітература:}

1. Аеминг Э. Выход из кризиса. М.: Иза-во "Альпина Бизнес Букс", 2007. 370 с.

2. Портер М. Конкуренция. М.: Издательский дом "Вильямс", 2000. 495 с.

3. Тейлор Ф. Принципы научного менеджмента. Экспертно-аналитический портал. URL: https://gtmarket.ru/laboratory/basis/3631 (дата звернення: 10.11.2021).

4. Recker J., Zelt S., Schmiedel T., Brocke J. Development and validation of an instrument to measure and manage organizational process variety. PLoS ONE. Project: Culture and Business Process Management. 2018. 13 (10). URL: https:// www.researchgate.net/publication/328419897_Development_and_validation_of_an_instrument_to_measure_and_manage_organizational_process_variety (дата звернення: 11.10.2021).

5. Davenport T.N., Short J.E. New Industrial Engineering: Information Technology and Business Process Redesign. Slogan Management Review, 1990. URL: https://sloanreview.mit.edu/article/ the-new-industrial-engineering-informationtechnology-and-business-process-redesign/ (дата звернення: 15.11.2021).

6. Zairi M. Business process management: a boundaryless approach to modern competitiveness. Business Process Management Journal, 1997, vol. 3 (1), pp. 64-80.

7. Репин В.В., Елиферов В.Г. Процессный подход к управлению. Моделирование бизнеспроцессов. М.: РИА "Стандарты и качество", 2004. 398 c.

8. Аогинов К.В. Теория и методы процессного управления промышленным предприятием. СПб.: СПбГИЭУ, 2008. 208 с.

9. Ойхман Е., Попов Э. Реинжиниринг бизнеса: реинжиниринг организаций и информационные технологии. М.: Финансы и статистика, 1997.333 с.

10. Репин B.В. Система стандартизации бизнес-процессов. M.: Business Studio. 2016. 14 с. 
URL: https:// www.FineXpert.ru (дата звернення: 01.11.2021).

11. Репин В.В. Бизнес-процессы компании: построение, анализ, регламентация. М.: РИА "Стандарты и качество", 2007. 240 с.

12. Хаммер М., Чампи Аж. Реинжениринг корпорации. Манифест революции в бизнесе. М.: Манн, Иванов и Фербер, 2006. 332 с.

13. Желєзняк А., Іваницький І. Управління ресурсами аграрних підприємств на основі оптимізації бізнес-процесів. Аграрна економіка. 2016. T. 9, № 1-2. C. 116-122. URL: http:// nbuv.gov.ua/UJRN/ae_2016_9_1-2_20 (дата звернення: 21.10.2021).

14. Яворська Т.І. Методологія вдосконалення управління бізнес процесами у сільськогосподарських підприємствах. Збірник наукових праць Таврійського державного агротехнологічного університету (економічні науки), 2018. Вип. 2 (37). С. 154-161.

15. Надточій I.I. Сутнісно-змістова характеристика бізнес-процесів та особливості управління ними. Вісник ХНАУ. 2020. № 4. Т. 2. C. $3-15$.

16. TeleManagement Forum. Telecom Operations Map. Evaluation Version 2.1. Morristown, NJ: TMForum, 2000. URL: http://or-rsv.narod.ru/ TMForum/TMForum_2.htm/ (дата звернення: 30.10.2021).

\section{References:}

1. Deming, E. (2007), Vyhod iz krizisa [Way out of the crisis], Alpina Business Books, Moscow, Russia.

2. Porter, M. (2000), Konkurencija [Competition], Williams, Moscow, Russia.

3. Taylor, F. (1991), "Principles of Scientific Management", available at: https://gtmarket.ru/laboratory/basis/3631 (Accessed $10 \mathrm{Nov}$ 2021).

4. Recker, J., Zelt, S., Schmiedel, T. and Brocke, J. (2018), "Development and validation of an instrument to measure and manage organizational process variety",PLoS ONE. Project: Culture and Business Process Management, vol. 13(10), available at: https://www.researchgate.net/ publication/328419897_Development_and_validation_of_an_instrument_to_measure_and_manage_organizational_process_variety (Accessed 11 Oct 2021).

5. Davenport, T.N. and Short, J.E. (1990), "New Industrial Engineering: Information Technology and Business Process Redesign",Slogan Management Review, available at: https://sloanreview.mit.edu/article/the-new-industrialengineering-information-technology-and- business-process-redesign/ (Accessed 15 Nov 2021).

6. Zairi, M. (1997), "Business process management: a boundaryless approach to modern competitiveness",Business Process Management Journal, Vol. 3 (1), Pp. 64-80.

7. Repin, V.V. and Eliferov, V.G. (2004), Processnyj podhod k upravleniju. Modelirovanie biznes-processov [Process approach to management. Modeling business processes], Standards and Quality, Moscow, Russia.

8. Loginov, K.V. (2008), Teorija i metody processnogo upravlenija promyshlennym predprijatiem [Theory and methods of process management of an industrial enterprise], Saint Petersburg, Russia.

9. Oikhman, E. and Popov, E. (1997), Reinzhiniring biznesa: reinzhiniring organizacij $\mathrm{i}$ informacionnye tehnologii [Business reengineering: organizations reengineering and information technologies], Finance and Statistics, Moscow, Russia.

10. Repin, V.V. (2016), "Business process standardization system", available at: https: // www.FineXpert.ru (Accessed 01 Nov 2021).

11. Repin, V.V. (2007), Biznes-processy kompanii: postroenie, analiz, reglamentacija [Business processes of the company: construction, analysis, regulation], Standards and Quality, Moscow, Russia.

12. Hammer, M. and Champy, J. (2006), Reinzheniring korporacii. Manifest revoljucii v biznese [Corporation reengineering. Manifesto of the revolution in business], Mann, Ivanov and Ferber, Moscow, Russia.

13. Zheluznyak, A. and Ivanitskiy, I. (2016), "Resource management of agricultural enterprises based on business process optimization",Ahrarna ekonomika, vol. 9, № 1-2, Pp. 116-122, available at: http://nbuv.gov.ua/UJRN/ae_2016_9_1-2_20 (Accessed 21 Oct 2021).

14. Yavorska, T.I. (2018), "Methodology for improving business process management in agricultural enterprises", Zbirnyk naukovykh prats' Tavrijs'koho derzhavnoho ahrotekhnolohichnoho universytetu (ekonomichni nauky), Vol. 2 (37), Pp. 154-161.

15. Nadtochiy, I.I. (2020), "Essential and semantic characteristics of business processes and features of their management",Bulletin of KhNAU, vol. 4, no. 2, Pp. 3-15.

16. TMForum (2000), "TeleManagement Forum. Telecom Operations Map. Evaluation Version 2.1. Morristown", available at: http://orrsv.narod.ru/TMForum/TMForum_2.htm/ (Accessed 30 Oct 2021).

Стаття надійшла до редакиії 22.12.2021 p. 